\title{
RELATIONSHIPS AMONG PHILOTARSID AND PSEUDOCAECILIID GENERA AND A PROPOSED NEW FAMILY BRYOPSOCIDAE (PSOCOPTERA)*
}

\author{
By Edward L. MOCKFORd \\ Department of Biological Sciences \\ Illinois State University \\ Normal, Illinois 61761
}

\section{INTRODUCTION}

In the classification of any group of organisms, views that have a long tradition are often difficult to put aside. We may weight certain characters heavily out of respect for such a traditional view. Weighting may even become an unconscious act if we uncritically include a particular character in the definition of a taxon. The character, then, comes to have absolute weight in our subsequent decisions about which subtaxa will be placed in the taxon and which will not. One must remember, however, that taxa, being constituted by organisms, have the capacity to evolve, and that any one character may have changed (evolved) in a subtaxon while others have not. We must not let a group definition come in the way of showing true relationships.

There has generally either been implied or expressed the view that adults in the psocopteran family Philotarsidae have three tarsomeres (Pearman 1936, Badonnel 1951, Smithers 1972, Thornton 1981). For some time, this was an indisputable fact, but Mockford and Evans (1976) and Mockford and Broadhead (1982), assigned species with two tarsomeres to this family.

Various authors have noted that adults in the family Pseudocaeciliidae have two tarsomeres (Pearman 1936, Badonnel 1951, Lee and Thornton 1967). This view remained unchanged until Meinander (1978) assigned a genus with three tarsomeres to this family. It appears now that adherence to the traditional view that Philotarsids should have three tarsomeres and Pseudocaeciliids should have two has led to a rather serious error in classification.

*Manuscript received by the editor June 8, 1984 
In a series of papers, Thornton and co-workers (Thornton and Smithers 1974, 1977, 1978, Thornton and New 1977a, b, Thornton, Wong, and Smithers 1977) have described numerous species of Philotarsidae from Australia, New Zealand, New Guinea, New Caledonia, and surrounding islands. Following these works, Thornton (1981) presented a classification of the Philotarsidae.

In an earlier work, Lee and Thornton (1967) described numerous species of Pseudocaeciliidae from southeastern Asia and the Islands of the South Pacific. If one compares the figures in this paper with figures for the Philotarsid genera Zelandopsocus and Austropsocus in the papers cited above, one sees numerous points of marked similarity.

\section{Methods}

The observations of notable similarities between two Philotarsid genera and several Pseudocaeciliid genera led me to make a comparison of as many of the genera of both families as the literature and material at hand allow (Table 1). Comparisons were made of 11 characters. All of those chosen hold constant (i.e., in the same state) in more than one genus but fewer than all genera of the assemblage. Therefore, they may be expected to hold information about relationships among these genera. Among characters which qualify in this way, the ones chosen are easily defined, and most of them have been described and/or figured in recent taxonomic works. Illustrations (Figs. 1-3) are included for characters which require them.

\section{Results AND Discussion}

In eight of the characters, both Austropsocus and Zelandopsocus, with three tarsomeres, agree with the Pseudocaeciliid genera. In presence of only a single row of setae on the M-Cu stem in the forewing, Zelandopsocus agrees with the other Philotarsid genera, while Austropsocus agrees with the Pseudocaeciliid genera. In the lateral tyne of the lacinial tip, Zelandopsocus, from published figures, appears to be intermediate between the other Philotarsids and the Pseudocaeciliids (but observation of $Z$. cumulus Thornton and New indicates closer proximity to Pseudocaeciliids), while Austropsocus agrees with the Pseudocaeciliids. Bryopsocus agrees with the other Philotarsids in five characters, with the Pseudocaeciliids in 
two, is clearly intermediate in two, while two characters remain unknown in this genus.

I conclude on the basis of these comparisons 1) that Austropsocus and Zelandopsocus, find their closest affinities with the Pseudocaeciliidae and should be placed there; 2) Bryopsocus is in several respects intermediate between these two families; it is unusual in several respects (see diagnosis, below) and apparently is best placed in a distinct family; 3 ) the forms remaining in Philotarsidae are the genera assigned to Subfamily Philotarsinae by Thornton (1981) (Thornton's other Subfamily, Zelandopsocinae, consists of Zelandopsocus, Austropsocus, and Bryopsocus).

It is necessary, then, to assign the genera placed in Philotarsidae by Thornton (1981) to three families: Philotarsidae Pearman, Bryopsocidae new family, and Pseudocaeciliidae Pearman. The three families may be diagnosed as follows:

Philotarsidae Pearman (type Psocus picicornis Fabricius). Most "outer" and all "inner" sensilla of distal margin of labrum occupying a trough in margin, 4 on its outer and 5 on its inner wall; 2 most lateral sensilla on outer surface of labrum (total of 11-"Type 1" of Table 1) (Fig. 1); lacinial tip with lateral tyne relatively broad; tarsi in adult 2- or 3-segmented; pretarsal claws each with a distinct preapical denticle and a slender pulvillus; $\mathrm{M}-\mathrm{Cu}$ stem in forewing generally with one rank of setae; abdomen lacking eversible vesicles; aedaegus rounded apically; external parameres not protruding much beyond tip of aedeagus; hypandrium lacking paired lateral lobes; subgenital plate one-lobed distally; second valvula bearing a low, rounded lobe medio-distally. Included genera: Philotarsus Kolbe, Aaroniella Mockford, Broadheadia Mockford and Evans (regarded as a synomym of Aaroniella by Thornton), Haplophallus Thornton, Tarsophilus Mockford and Broadhead, Latrobiella Thornton.

Bryopsocidae new family (type Austropsocus townsendi Smithers). Lacinial tip with lateral tyne somewhat less broad than in Philotarsidae; tarsi in adult 3-segmented; pretarsal claws each with a distinct preapical denticle; $\mathrm{M}-\mathrm{Cu}$ stem in forewing with two ranks of setae; $\mathrm{Cu}_{2}$ in forewing with or without setae; hypandrium lacking paired lateral lobes but with a single low, rounded lobe on each side; aedeagus pointed apically; external parameres protruding well beyond tip of aedeagus; subgenital plate one-lobed distally; second 

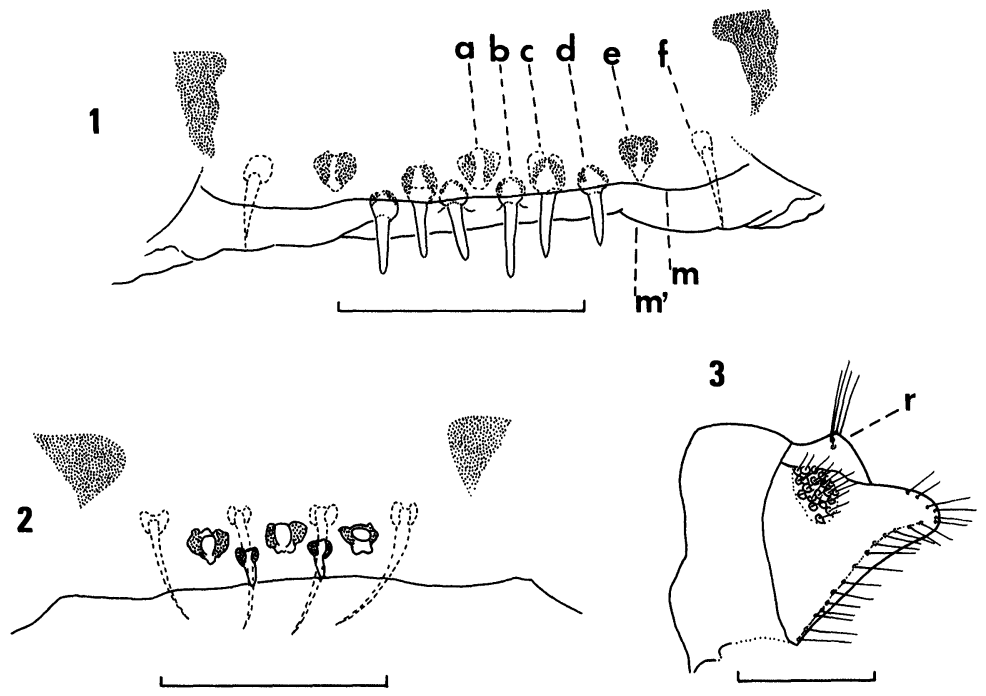

Figs. 1-3. Structures of Philotarsid and Pseudocaeciliid psocids. Figs. 1 and 2. Distal margin of labrum in posterior view showing sensilla (scale $=0.05 \mathrm{~mm}$ ). Fig. 1 . Latrobiella paraguttata Thornton and New , type 1: 11 sensilla of three series, a, c, and e lying immediately under a posterior membranous fold $(\mathrm{m}), \mathrm{b}$ and $\mathrm{d}$ lying deeper, perhaps on inner surface of second membranous fold $\left(\mathrm{m}^{\prime}\right)$, and $f$ lying on anterior surface. Fig. 2. Zelandopsocus cumulus Thornton and New $ᄋ$, type 2: nine sensilla in two series, five shown in solid lines on posterior surface, four shown in dashed lines on anterior surface. Fig. 3. Zelandopsocus cumulus $\$$, clunium, epiproct, and left paraproct in lateral view; $r=$ setigerous ridge or flap of epiproct (scale $=0.2 \mathrm{~mm}$ ).

valvula bearing a blunt-tipped process medio-distally. Included genus: Bryopsocus Thornton, Wong, and Smithers.

Several unusual features were noted for Bryopsocus by Thornton, Wong, and Smithers (1977). These include hardening and fusion of female abdominal terga, a setose forewing membrane, and possibly wings of macropterous males being held flat over the abdomen at rest, those of one side overlapping those of the other. These characters, along with the unusual habitat of moss, serve to strengthen the view that this genus should be assigned its own family. The two species which have been assigned to Bryopsocus differ rather markedly, and it is not clear that all of the generic characters (derived from the type species) apply to both species. 
Pseudocaeciliidae Pearman (type Psocus citricola Ashmead). Distal margin of labrum with 4 sensilla on outer wall in form of relatively long, thin-walled setae with acuminate tips and 5 sensilla of usual form in pockets or shallow trough on inner wall ("type 2" of Table 1) (Fig. 2); lacinial tip with lateral tyne relatively slender; tarsi in adult 2- or 3-segmented; pretarsal claws generally lacking preapical denticle, at most with a minute denticle (Cladioneura, some Pseudocaecilius, Mesocaecilius quadrimaculatus Okamoto); pulvillus broad; $\mathrm{M}-\mathrm{Cu}$ stem in forewing generally with two ranks of setae; abdomen with one or more ventral eversible vesicles; hypandrium generally with paired lateral lobes or processes; aedeagus pointed apically; external parameres extending well beyond tip of aedeagus; subgenital plate bilobed distally; second valvula bearing an acuminate process medio-distally.

The curious genus Trimerocaecilius Meinander was placed here, apparently correctly, by its author (Meinander 1978). It is known to differ from the above description by the following characters: lacinial tip with lateral tyne short and truncate; pretarsal claw with a well formed preapical denticle; pulvillus slender; hypandrium with no trace of lateral lobes or processes. I did not include Trimerocaecilius in my Table 1 because information is vague or lacking for it about three of the characters being compared: nature of the apex of the aedeagus, nature of the labral sensilla, and presence or absence of abdominal eversible vesicles.

In addition to the unifying characters noted in Table 1, certain other observations bear on the unification of the 2-tarsal segmented and 3-tarsal segmented forms of this family. The dorsal setose flap noted by Thornton, Wong, and Smithers (1977) of the female epiproct of Zelandopsocus, (the "flap" is a rather low ridge in Z. cumulus, Fig. 3), which always bears a transverse row of setae, is also present in Pseudocaecilius, Ophiodopelma, and Pseudoscottiella. The endophallic sclerotizations of some species of Zelandopsocus, and Austropsocus, are similar to those of some species of Allocaecilius, Cladioneura, Heterocaecilius, Scytopsocopsis, and in Mesocaecilius quadrimaculatus. Included genera: Pseudocaecilius Enderlein, Allocaecilius Lee and Thornton, Allopsocus Banks, Austropsocus, Smithers, Cladioneura Enderlein, Heterocaecilius Lee and Thornton, Mesocaecilius Okamoto, Ophiodopelma Enderlein, Phallocaecilius Lee and Thornton, Pseudoscottiella Badonnel, 
Table 1. Distribution of characters in some genera of Philotarsidae and Pseudocaeciliidae.

\begin{tabular}{|c|c|c|c|c|c|}
\hline & $\begin{array}{c}\# \\
\text { Tarso- } \\
\text { meres }\end{array}$ & $\begin{array}{l}\text { Claw w } \\
\text { subap. } \\
\text { denticle }\end{array}$ & $\begin{array}{c}\text { Hypandrium } \\
\text { w paired } \\
\text { lat. lobes/ } \\
\text { processes }\end{array}$ & $\begin{array}{l}\text { Aedeagus } \\
\text { pointed } \\
\text { (rounded) } \\
\text { apically }\end{array}$ & $\begin{array}{l}\text { Ext. } \\
\text { parameres } \\
\text { reach far } \\
\text { beyond } \\
\text { aedeagus }\end{array}$ \\
\hline Philotarsus & 3 & + & - & Rounded & - \\
\hline Haplophallus & 3 & + & - & Rounded & - \\
\hline Aaroniella & 3 & + & - & Rounded & - \\
\hline Latrobiella & 3 & + & - & Rounded & - \\
\hline Tarsophilus & 2 & + & - & Rounded & - \\
\hline Bryopsocus & 3 & + & - & Pointed & + \\
\hline Zelandopsocus & 3 & - & + & Pointed & + \\
\hline Austropsocus & 3 & - & + & Pointed & + \\
\hline Pseudocaecilius & 2 & $\begin{array}{c}- \\
(\text { some }+)^{*}\end{array}$ & \pm & Pointed & + \\
\hline Mesocaecilius & 2 & $\begin{array}{c}- \\
(\text { some }+)^{*}\end{array}$ & + & Pointed & + \\
\hline Ophiodopelma & 2 & - & + & Pointed & + \\
\hline Scytopsocus & 2 & - & + & Pointed & + \\
\hline
\end{tabular}

*In some species of Pseudocaecilius, and in Mesocaecilius quadripunctatus, there is a minute denticle on one claw per tarsus. 


\begin{tabular}{|c|c|c|c|c|c|}
\hline $\begin{array}{l}\text { Subgen. } \\
\text { plate } \\
1 / 2 \text { lobed } \\
\text { distally }\end{array}$ & $\begin{array}{c}\text { Labral } \\
\text { sensilla: } \\
\text { type } 1 \text { or } 2\end{array}$ & $\begin{array}{l}\text { Lacinial } \\
\text { tip. } \\
\text { lat. tyne }\end{array}$ & $\begin{array}{c}\text { Setae on } \\
\text { M-Cu stem } \\
\text { in FW: } 1 \text { or } \\
2 \text { ranks }\end{array}$ & $\begin{array}{l}\text { Appendage of } \\
\text {.2nd valvula } \\
\text { rounded/ptd. }\end{array}$ & $\begin{array}{c}\text { Abdom. } \\
\text { eversible } \\
\text { vesicles }\end{array}$ \\
\hline 1 & 1 & Broad & 1 & Rounded & - \\
\hline 1 & 1 & Broad & 1 & Rounded & - \\
\hline 1 & 1 & Broad & 1 & Rounded & - \\
\hline 1 & 1 & Broad & 1 or 2 & Rounded & - \\
\hline$?$ & 1 & Broad & 1 & $?$ & - \\
\hline 1 & $?$ & Inter. & 1 & Blunt Point & $?$ \\
\hline 2 & 2 & $\begin{array}{l}\text { Inter. or } \\
\text { narrow }\end{array}$ & 1 & Pointed & + \\
\hline 2 & 2 & Narrow & 2 & Pointed & + \\
\hline 2 & 2 & Narrow & 2 & Absent & + \\
\hline 2 & 2 & Narrow & 2 & Pointed & + \\
\hline 2 & 2 & Narrow & 2 & Pointed & + \\
\hline 2 & 2 & Narrow & 2 & Pointed & + \\
\hline
\end{tabular}


Scottiella Enderlein, Scytopsocopsis Lee and Thornton, Scytopsocus Roesler, Trichocaecilius Badonnel, Trimerocaecilius Meinander, Zelandopsocus Tillyard.

It is likely that the adaptive zones of the three families are generally distinct. The combination of absence of (or only minute) preapical denticles on the pretarsal claws, possession of broad pulvilli, and presence of ventral abdominal eversible vesicles in most Pseudocaeciliidae probably signifies leaf dwelling, which is known for several of the genera. Presence of preapical denticles of the pretarsal claws, slender pulvilli, and absence of abdominal eversible vesicles in Philotarsidae may signify bark dwelling, as is the case in the Philotarsus and Aaroniella species which I have observed. Some of these characters remain unrecorded for Bryopsocidae. The type species of this family has been taken most frequently on moss, suggesting a unique habitat for this group.

The correlation of some of the characters to habitat noted in the above paragraph suggests the possibility of convergence between three-tarsal-segmented forms (Philotarsidae sensu Thornton, 1981) and two-tarsal-segmented forms (Pseudocaeciliidae sensu Lee and Thornton, 1967), but the hypothesis of phylogenetic affinity proposed here appears to be the simpler one and is supported by several characters which are not habitat-correlated.

Can a sister-group relationship be seen among these families? In dealing with this question, one must note that Smithers (1967) presented a very strong argument for close proximity of Family Pseudocaeciliidae and Family Calopsocidae. This idea is not at all weakened by addition of Austropsocus and Zelandopsocus to Pseudocaeciliidae. Unless Calopsocidae, in which forewing venation has become complex and plastic, was derived from within the venationally conservative Pseudocaeciliidae, these two families must have phylogenetic sister relationship.

Judging from the extent of character sharing shown in Table 1, Bryopsocidae is probably the phylogenetic sister group of the common stem of Pseudocaeciliidae and Calopsocidae. However, certain intriguing similarities occur in the wing, tarsal, and female genitalic characters of Calopsocidae and Archipsocidae which require further exploration. Secondary suppression of some of the Pseudocaeciliid characters may also have produced Family Trichopsocidae. 
The Philotarsidae as defined here may be the sister group of the common stem of Bryopsocidae plus the Pseudocaeciliid-Calopsocid branch, but not necessarily. An argument of about equal strength could be made for a liaison between Philotarsidae and Mesopsocidae or Philotarsidae and Elipsocidae. I do not believe that present data are sufficient to solve this problem.

\section{SUMMARY}

A comparison of genera of Families Philotarsidae and Pseudocaeciliidae indicates that the classification of Family Philotarsidae proposed by Thornton (1981) is unacceptable. The two major genera of his subfamily Zelandopsocinae (Zelandopsocus Tillyard and Austropsocus Smithers) are more closely related to Family Pseudocaeciliidae than to his other subfamily, Philotarsinae. One new family, Bryopsocidae, is erected for Bryopsocus Thornton, Wong, and Smithers. This genus is intermediate in several respects between Philotarsidae and Pseudocaeciliidae (both families as redefined here) and is unique in several others. Families Philotarsidae and Pseudocaeciliidae are redefined and the named genera assigned to each are listed. Zelandopsocus and Austropsocus are transferred from Philotarsidae to Pseudocaeciliidae. Pseudocaeciliidae and Calopsocidae appear to be sister groups. Bryopsocidae may be a sister group to this pair, but certain alternatives are possible. Philotarsidae may be a sister group to the trio PseudocaeciliidaeCalopsocidae-Bryopsocidae, but several other families, including Archipsocidae, Trichopsocidae, Elipsocidae, and possibly Mesopsocidae would have to be investigated for a complete understanding of the Phylogeny of these groups.

\section{ACKNOWLEDGMENTS}

This is part of a study supported by National Science Foundation grant no. BSR-8219659 to Illinois State University. An earlier draft of this work was read by Dr. A. Badonnel of the Laboratoire de Zoologie (Arthropodes), Muséum National d'Histoire Naturelle, Paris, and by Dr. Gary E. Eertmoed, Department of Biological Sciences, Chicago State University. Useful suggestions from these colleagues permitted notable improvements in the final draft. 


\section{Literature Cited}

Badonnel, A. 1951. Ordre des Psocoptères, in Grassé, P. Traité de Zoologie, 10, Fasc. 2:1301-1340.

Lee, S. S. and I. W. B. Thornton. 1967. The Family Pseudocaeciliidae (Psocoptera)-A reappraisal based on the discovery of new Oriental and Pacific species. Pacific Insects Monogr. 16:1-116.

Meinander, M. 1978. Two new species of Pseudocaeciliidae (Psocoptera) from SE Europe. Ent. Scand. 9:1-6.

MOCKFORD, E. L. AND E. BROADHEAD. 1982. A new genus and two new species of Philotarsidae (Insecta: Psocoptera) from East Africa. Journ. Nat. Hist. 16:431-437.

MOCKFORD, E. L. AND H. A. Evans. 1976. Descriptions and records of some Philotarsidae from Trinidad, West Indies (Psocoptera). Florida Entomologist 59:171-181.

Pearman, J. V. 1936. The Taxonomy of the Psocoptera: preliminary sketch. Proc. Royal Entomol. Soc. Lond. 5:58-62.

Smithers, C. N. 1967. On the relationships of the Calopsocidae (Psocoptera). Journ. Austral. Entomol. Soc. 6:61-64.

Smithers, C. N. 1972. The classification and phylogeny of the Psocoptera. Austral. Mus. Mem. 14:1-349.

THORNTON, I. W. B. 1981. The systematics, phylogeny, and biogeography of the psocopteran family Philotarsidae. Syst. Entomol. 6:413-452.

Thornton, I. W. B. And T. R. New. 1977a. Philotarsidae (Psocoptera) of the Bismark Archipelago. Pacific Insects 17:151-157.

Thornton, I. W. B. And T. R. New. 1977b. The Philotarsidae (Insectas: Psocoptera) of Australia. Austral. Journ. Zool. Suppl. Ser. 54:1-62.

Thornton, I. W. B. and C. N. Smithers. 1974. The Philotarsidae (Psocoptera) of New Caledonia. Pacific Insects 16:177-243. 

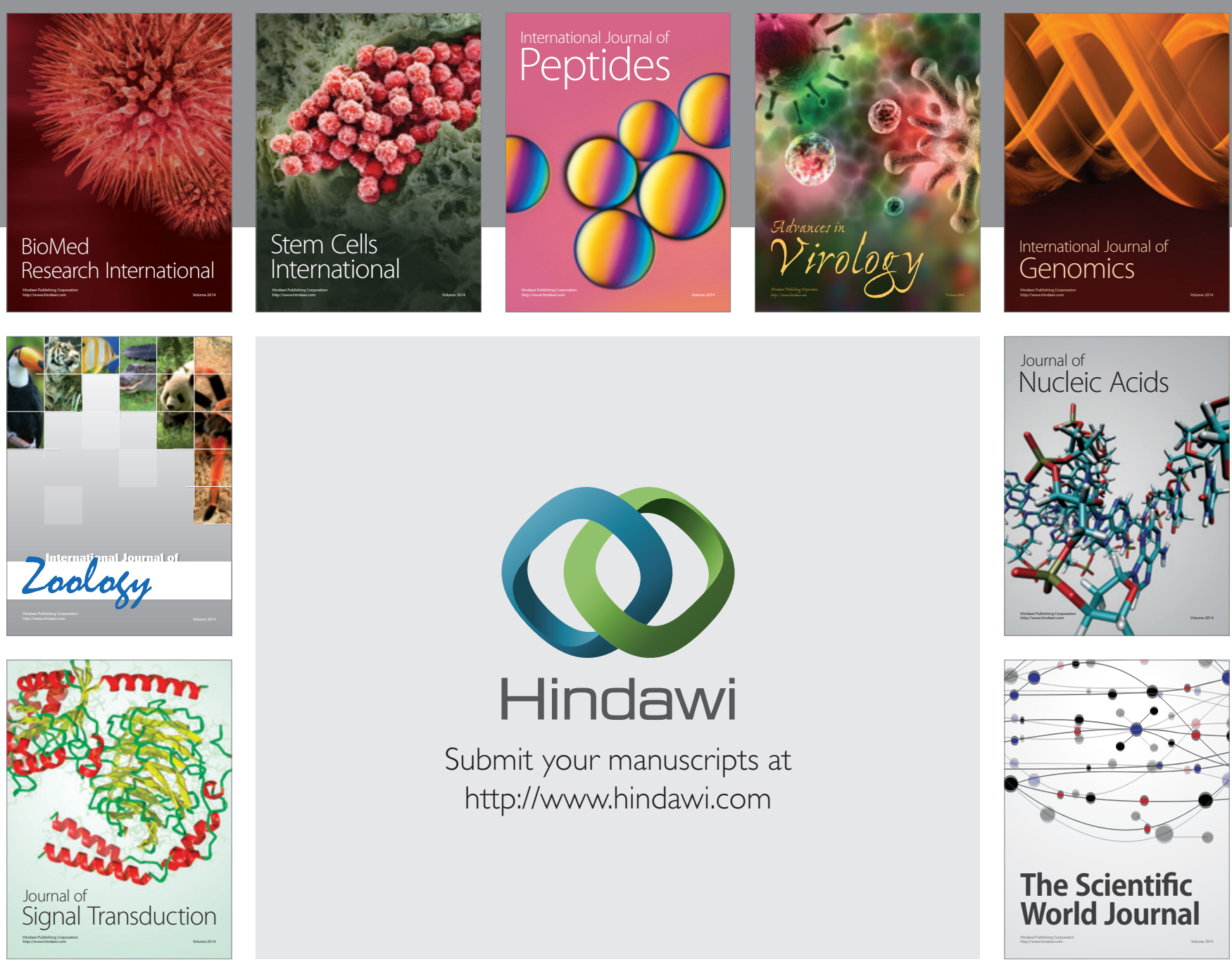

Submit your manuscripts at

http://www.hindawi.com
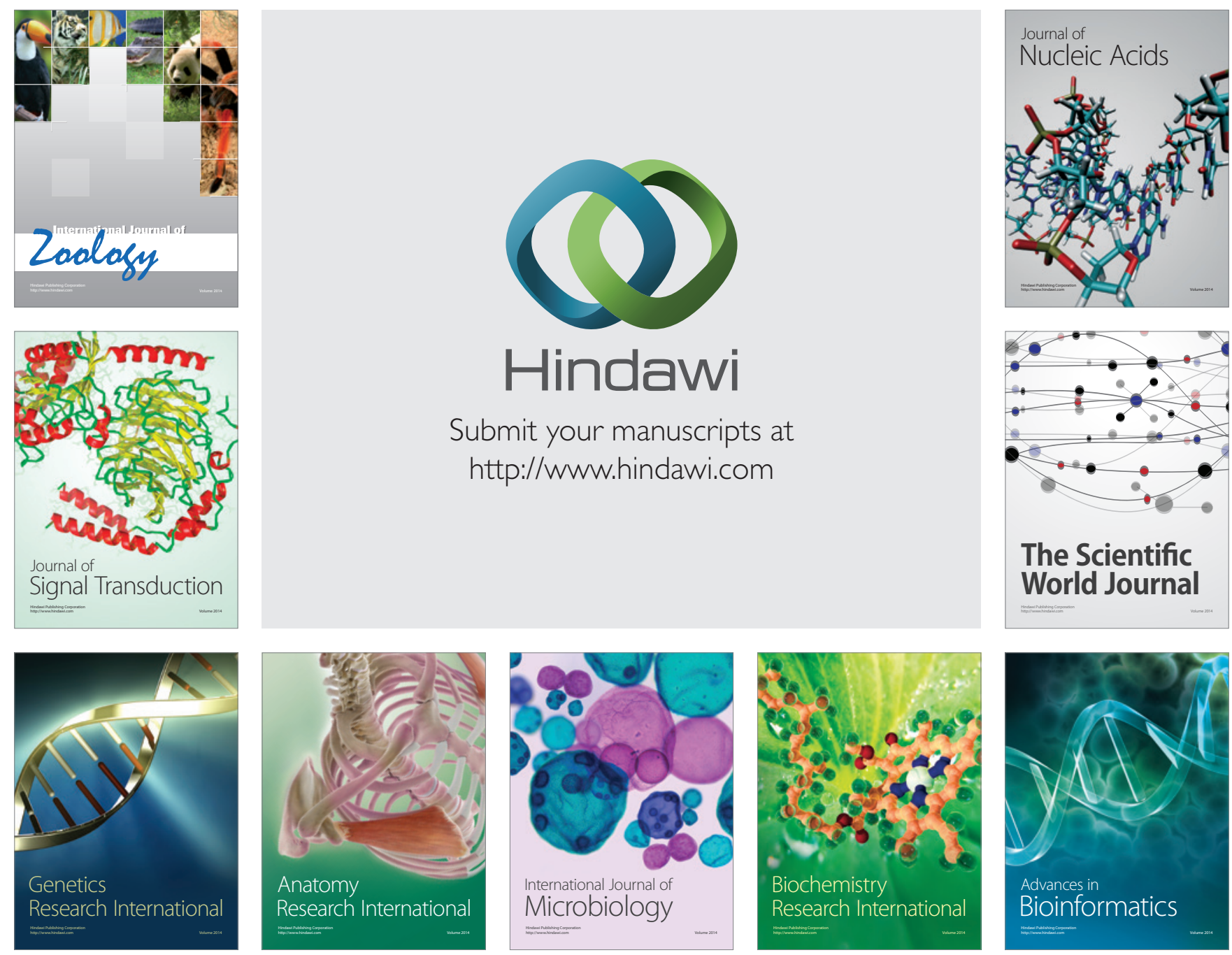

The Scientific World Journal
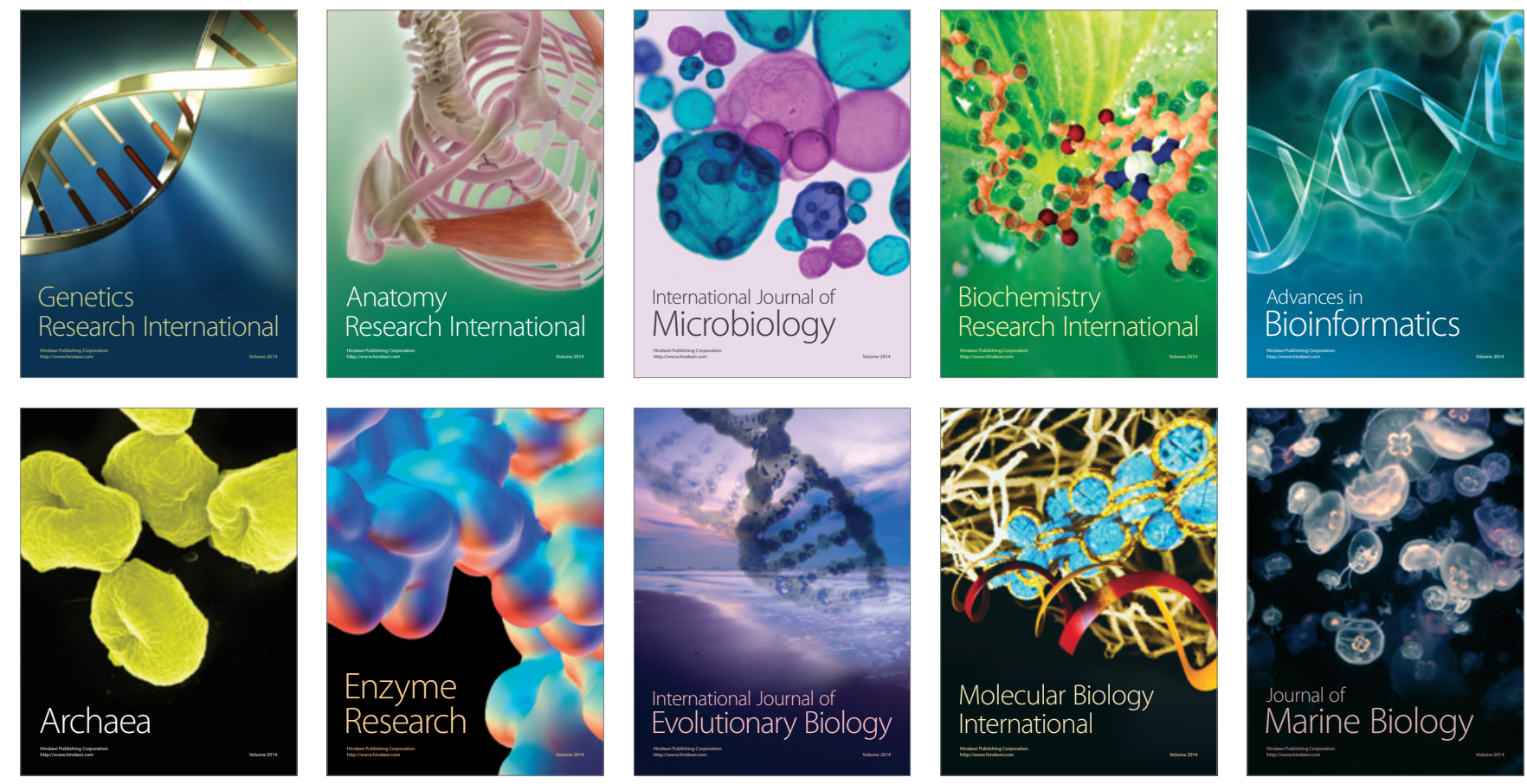